\title{
Human mobility on the Brazilian coast: an analysis of strontium isotopes in archaeological human remains from Forte Marechal Luz sambaqui
}

\author{
MURILO Q.R. BASTOS ${ }^{1,2}$, SHEILA M.F. MENDONÇA DE SOUZA ${ }^{2}$, ROBERTO V. SANTOS ${ }^{3}$, \\ BÁRBARA A.F. LIMA ${ }^{3}$, RICARDO V. SANTOS ${ }^{1,2}$ and CLAUDIA RODRIGUES-CARVALHO ${ }^{1}$ \\ ${ }^{1}$ Setor de Antropologia Biológica, Departamento de Antropologia, Museu Nacional, \\ Universidade Federal do Rio de Janeiro, Quinta da Boa Vista, s/n, 20940-040 Rio de Janeiro, RJ, Brasil \\ ${ }^{2}$ Departamento de Endemias, Escola Nacional de Saúde Pública, Fundação Oswaldo Cruz, \\ Rua Leopoldo Bulhões, 1480, 21041-210 Rio de Janeiro, RJ, Brasil \\ ${ }^{3}$ Departamento de Geoquímica e Recursos Minerais, Insituto de Geociências, \\ Universidade de Brasília, 70910-900 Brasília, DF, Brasil
}

Manuscript received on August 8, 2009; accepted for publication on August 16, 2010

\begin{abstract}
This study investigated strontium isotopes in the dental enamel of 32 human skeletons from Forte Marechal Luz sambaqui (shellmound), Santa Catarina, Brazil, aiming at identifying local and non-local individuals. The archeological site presents pot sherds in the uppermost archeological layers. Dental enamel was also examined from specimens of terrestrial fauna $\left({ }^{87} \mathrm{Sr} /{ }^{86} \mathrm{Sr}=0.71046\right.$ to 0.71273$)$ and marine fauna $\left({ }^{87} \mathrm{Sr} /{ }^{86} \mathrm{Sr}=0.70917\right)$. The ${ }^{87} \mathrm{Sr} /{ }^{86} \mathrm{Sr}$ isotope ratio for individuals classified as locals ranged from 0.70905 to 0.71064 and was closer to the isotope ratio of the seawater than to the ratio of the terrestrial fauna, indicating a strong influence of marine strontium on the inhabitants of this sambaqui. The results indicate the existence of three non-local individuals $\left({ }^{87} \mathrm{Sr} /{ }^{86} \mathrm{Sr}=0.70761\right.$ to 0.70835$)$, buried in both the level without pottery and the layer with pottery, possibly originated from the Santa Catarina Plateau, close to the municipality of Lages, or from the Curitiba Plateau. The occurrence of a slight difference between the isotope ratios of local individuals buried in the archeological layer without pottery, when compared to those in the layer with pottery, suggests a possible change in dietary patterns between these two moments in the site's occupation.
\end{abstract}

Key words: Brazil, human mobility, isotopes, prehistory, shellmounds, strontium.

\section{INTRODUCTION}

Since the 1990s, the analysis of ${ }^{87} \mathrm{Sr} /{ }^{86} \mathrm{Sr}$ isotopes in human skeletal remains has been used extensively to identify past human mobility patterns. Based on the relationship between the isotopic composition of these remains (bones and teeth specially) and that of rocks in a given location, it is possible to distinguish individuals that grew up and died in the same region, from those who did not (Bentley et al. 2004). This is possible with dental enamel analysis, since the permanent dentition is formed during the first decade of life, and the strontium

Correspondence to: Ricardo Ventura Santos

E-mail: santos@ensp.fiocruz.br deposited in the enamel remains the same for the rest of the individual's life.

Strontium isotope analysis has been useful in various archeological studies, including those focusing on settlement and migration patterns in ancient Maya communities (Hodell et al. 2004), Central Europe (Bentley et al. 2003, Grupe et al. 1997), in communities in the Southwest of North America (Ezzo et al. 1997, Price et al. 2000), Great Britain (Budd et al. 2004, Evans et al. 2006), Peru and Bolivia (Knudson et al. 2004), and the Nile Valley (Buzon 2006), among others. A recent study by Wilson et al. (2007) used strontium isotope analysis to demonstrate that some individuals sacrificed in Inca rituals came from quite distant regions. 
Studying ancient human mobility is crucial since, in addition to increasing the understanding of population dynamics, it sheds light on the spread of contagious diseases in the past (Apostolopoulos and Sönmez 2007), as well as on the introduction of cultural elements, changes in dietary patterns, and other aspects in the lives of ancient people (Prous 1991). Although various authors have studied the mobility of prehistoric populations using strontium isotopes, as mentioned above, this technique has not been systematically explored in prehistoric Brazilian coastal populations. These populations spread over a large geographic area, and there is even debate over their relationship and contacts with peoples from the interior (Prous 1991). Certain findings from inland sites, like zoolites (artifacts in the shape of animals, made of polished stone, typical of the coast), as well as typical plateau artifacts like pottery from the Itarare Tradition in coastal sites, contribute to the hypothesis of contact between coastal and inland populations (Beck 1971).

The current study focuses on residential mobility, aiming to detect local and non-local individuals from pre-Colombian populations on the southern coast of Brazil, based on strontium isotope analysis. As far as we know, this is the first study published in archeology of prehistoric populations on the Brazilian coast that uses this geochemical technique. We analyzed individuals buried in Forte Marechal Luz sambaqui, located on the northern coast of the state of Santa Catarina. The uppermost archaeological layers in this site yielded pottery sherds associated with a typical ceramic tradition from the southern Brazilian Plateau. Such evidence suggests a contact between the population that inhabited this sambaqui and inland groups. We also discuss the variations in isotope ratios between individuals buried in two distinct archeological sequences (the older without evidence of pottery, and the younger with presence of pottery sherds) from Forte Marechal Luz site, with the aim of allowing inferences on dietary patterns.

\section{SAMBAQUIS, LATER COASTAL OCCUPATIONS, AND EVIDENCE OF MOBILITY}

In Brazil, sambaquis are both the most numerous coastal sites and the best known to archeologists (Lima 1999-
2000, Gaspar et al. 2008). Sambaquis are cultural deposits of varying size and stratigraphy made primarily from the accumulation of seashells, sand, or earth during pre-colonial times. These constructions contain the remains of fishing and gathering cultures, such as utensils, weapons, adornments, food scraps, ash, charcoal from old fires, human burials and vestiges of old huts.

Coastal sambaquis date from 8,000 years BP (Calippo 2004) to the first millennium AD (Lima 19992000), although most sambaquis dates are concentrated between $4000 \mathrm{BP}$ and $2000 \mathrm{BP}$. These shellmound sites are usually located in highly productive bay and lagoon ecotones, where the mingling of salt and fresh waters supports mangrove vegetations and abundant shellfish, fish and aquatic birds (Gaspar et al. 2008). These areas of high biotic productivity allowed a high-density population for the sambaqui's builders (Gaspar 1991, Lima 1999-2000).

The sambaqui populations were considered fisherhunter-gatherers. However, recent studies have demonstrated the use of some plants in the diet of these groups (Scheel-Ybert 2001, Wesolowski 2007), which could suggest incipient horticulture, as well as systematic management of naturally abundant plants. It has also been shown that a significant part of the sambaqui dwellers' diet was based on fishing (Figuti 1993, De Masi 2001).

Although it has been suggested that the Serra do Mar mountain could have acted as a geographic barrier, limiting the access of these coastal populations to the plateau (Lima 1999-2000), some specific stretches of the terrain have a smoother topography, which certainly facilitated population movements between the coast and interior that appear to have followed the region's main river basins, like the Ribeira valley in São Paulo (Barreto 1988), the Itajaí valley in Santa Catarina, and the Jacuí valley in Rio Grande do Sul (Ribeiro et al. 1977). Archeological evidence, like the presence of artifacts, also supports these population movements since they have been found in both coastal and interior archaeological sites. Various sambaquis along the Ribeira valley, including some with older dates than the coastal ones, are located along this river and have yielded remains of marine animals, as well as typical coastal fauna and cultural vestiges. In some cases, these occupations appear to be more consistent with well-es- 
tablished coastal groups that moved inland, rather than inland populations exploring fluvial resources while moving toward the sea (Lima 1999-2000). Opposite movements, or the mobility of individuals from inland to coastal communities, are mainly suggested by the presence of ceramics on sambaquis. The presence of coastal shells in inland sambaquis, and pine starch as a food remain at coastal sambaquis (Wesolowsky 2007, Wesolowsky et al. 2010), besides the cultural trace represented by the Itararé ceramics in costal sambaquis and inland villages of pottery makers, is consistent with the hypothesis of mobility.

The ceramics at the coastal sites starts about 2000 years ago, when various fisher-hunter-gatherer sites also began to emerge along the Brazilian coast. Their remains are shallow sites, with sandier sediments, without the characteristic accumulation of seashells and less visual impact on the coastal landscape. They are characterized by more evident accumulation of fish bones and in many cases, they seem to constitute the most recent occupational layer in typical sambaquis. These sites are frequently identified in the literature as belonging to different groups of sambaqui-builders (Prous 1991). Their occurrence generally overlaps the chronology of sambaqui sites, and the archeological evidence points to groups that were equally adapted to life at the coastal environment, both in terms of subsistence and material culture, differing little from the sambaqui groups. The main difference is the presence of pottery associated with these occupations, identified as belonging to the Itarare Ceramic Tradition, located mainly in the inland of Santa Catarina and Paraná, and also in the northern coast of Santa Catarina (Beck 1972, Bandeira 2004).

Therefore, the presence of ceramic traditions belonging to the plateau groups at the coastal sites reinforces the hypothesis of contact between inland populations and sambaqui builders. In the field of bioarcheology, a research on the possible relations between prehistoric coastal and inland groups has also been based on the study of cranial morphology using multivariate statistical methods. Neves (1988) indicated genetic differences between ceramic and pre-ceramic populations on the northern coast of Santa Catarina. According to this author, long after the initial occupation of the coast by the sambaqui builders, some plateau populations arrived at the northern coast of Santa Catarina. Based on comparative analyses of craniofacial morphology, Mello e Alvim and Mendonça de Souza (1984) suggested a similarity between individuals buried in Forte Marechal Luz site and contemporaneous Xokleng Indians.

\section{STRONTIUM ISOTOPES AND THEIR ARCHEOLOGICAL APPLICABILITY}

Strontium ( $\mathrm{Sr}$ ) is a chemical element that occurs in the form of four stable isotopes with different abundances, ${ }^{84} \mathrm{Sr}(0.56 \%),{ }^{86} \mathrm{Sr}(9.87 \%),{ }^{87} \mathrm{Sr}(7.04 \%)$, and ${ }^{88} \mathrm{Sr}\left(82.53 \%\right.$ ) (Faure and Powell 1972). ${ }^{87} \mathrm{Sr}$ originates from the radioactive decay of rubidium $\left({ }^{87} \mathrm{Rb}\right)$, which has a half life of $4.9 \mathrm{Ga}$. Meanwhile, the isotope ${ }^{86} \mathrm{Sr}$ is not radiogenic, i.e., its abundance is not altered by the radioactive decay of other elements.

Due to $\mathrm{Rb}$ decay, the abundance of the ${ }^{87} \mathrm{Sr}$ isotope in rocks and soils deriving from it varies, and depends on factors such as the rock age and $\mathrm{Rb}$ concentration. For example, among geological formations with the same amount of $\mathrm{Rb}$, the oldest ones have more time to produce ${ }^{87} \mathrm{Sr}$ through the radioactive decay of ${ }^{87} \mathrm{Rb}$, thus generating materials with higher ${ }^{87} \mathrm{Sr} /{ }^{86} \mathrm{Sr}$ ratios as when compared to younger formations (Faure 1986).

In the weathering cycle, i.e., in the process of soil formation from rocks, the strontium isotope ratio does not change in other words, there is no isotopic fractionation (Faure 1986, Sillen and Kavanagh 1982). Thus, the strontium introduced into the food chain by a given food does not change significantly in its isotope ratio. Although no isotopic fractionation occurs along the food chain, the isotopic composition of strontium found in plants and animals does not have a single origin, but results from a mixture of strontium of diverse origins (air, water, and soil) (Miller et al. 1993, Faure 1986).

Based on its chemical characteristics, mainly ionic radius and valence, strontium behaves in the organism like calcium, and replaces the last one in hydroxyapatite crystals, in the mineral matrix of calcified tissues like bones and teeth (Faure 1986). Bone undergoes a continual replacement of its inorganic phase due to the remodelation of the mineral matrix (Ericson 1986), so that measurements of bone strontium reflect the later years of the individual's life (Hillson 1996). 
Unlike bones, dental enamel does not undergo remodeling over the course of life, so that the strontium present in enamel corresponds to that assimilated during the individual's childhood and early adolescence, in the period of the enamel formation (Hillson 1996). Therefore, the strontium isotopic composition of hydroxyapatite crystals in individuals' dental enamel is directly related to the mean strontium isotopic composition in the food and water ingested during youth and consequently to the isotopic characteristic of the region in which the individual grew up (Ericson 1986, Price et al. 1998).

Applying this reasoning to individuals found in an archeological site, it is possible to identify the migrants among the locals by comparing each individual's tooth value to the isotopic signature of the region where the site is located (Schweissing and Grupe 2003, Wright 2005). Local individuals have strontium isotopic ratios that reflect the geological settings of the area in which they have inhabited. In contrast, non-locals more probably come from regions with a distinct geology that may present either lower or higher strontium isotopic values. Thus, assuming that individuals with different isotopic values are non-locals, strontium isotopes analysis may be used to reconstruct human mobility patterns in the past (Bentley et al. 2003).

In order to identify local and non-local individuals, it is essential to know the isotopic signature of the region in which the individuals were buried. In general, the local isotopic composition can be obtained from samples of dental enamel taken from the fauna in the region where the site is located, with a preference for small and less mobile herbivores, like rodents (Price et al. 2002). This source of strontium is known as a biological source of the local isotopic signature. In addition to fauna, the geological maps of the target regions are essential for a proper understanding of the results.

The chemical interaction between water and soil and bones and teeth leads to exchanges with the microenvironment and can alter the original isotopic composition of the remains, a process known as diagenesis. The adherence of post-mortem chemical elements to the skeletal remains is practically unavoidable (Hoppe et al. 2003, Buzon 2006), while the magnitude of its effects is related to the tissues' porosity (Bentley et al. 2004). Although various studies have indicated a high occurrence of diagenesis in bone tissues, this type of contamination has been observed to occur to a lesser degree in dental enamel tissues (Grupe et al. 1997, Montgomery et al. 1999). With the aim of eliminating the effects of surface diagenetic contamination, some studies have used techniques involving mechanical and chemical cleaning of samples (Price et al. 2004, Hodell et al. 2004, Buzon 2006).

\section{MATERIALS AND METHODS}

\section{STUdy AREA}

Forte Marechal Luz site is found on the slope of João Dias hill, close to the fort that named the site. Located at the São Francisco do Sul island, in northern Santa Catarina State $\left(26^{\circ} 9^{\prime} 56^{\prime \prime S}\right.$ and $\left.48^{\circ} 31^{\prime} 56^{\prime \prime} \mathrm{W}\right)$, the site was excavated by the archeologist Alan L. Bryan in 1960. At the time of the excavation, in the 1960s, the site was only a partial testimony because in the past a large portion of the deposit had been removed for road paving (Bryan 1997). Bryan classified the site as a sambaqui, but the stratigraphic levels show a series of prehistoric occupations that extended over nearly four millennia $(4290 \pm 130 \mathrm{BP}$ to $640 \pm 100 \mathrm{BP})$, in more or less continuous fashion, with a few periods of abandonment (Bryan 1993). The geology on São Francisco island is characterized by the abundant presence of marine deposits (beach sediments and coastal cordons) and mixed deposits (unconsolidated debris of fluvialmarine and lacustrine origin), represented by Quaternary sediments that overly Proterozoic gneisses and granitic rocks (Higashi et al. 2001).

The excavation area was $70 \mathrm{~m}^{2}$, having reached a maximum depth of $6.5 \mathrm{~m}$ (mean $3 \mathrm{~m}$ ) and revealed 23 depositional strata, which were separated into "occupational zones" (Bryan 1993). These occupational zones are believed to represent distinct moments of occupation in time, with similarities to each other, but also presenting minor cultural differences, especially in the repertoire of artifacts, manufacturing technique, and types of burials. As in other sambaquis of the same bay, Anomalocardia brasiliana clamshells and fish bones predominate in the matrix composition in all the strata. Forte Marechal Luz site presents typical sambaqui layers (occupational levels I, II, III, IV, and V and layer $6 \mathrm{~B})$ and some other upper layers that are characteristic 
of ceramic occupations in the same region, identified as belonging to the Itararé Tradition (occupational levels VI and VII). The human burials are only found in the upper occupational levels, corresponding to two chronological periods at the end of the site's occupations. The human burials were located in layer $6 \mathrm{~B}(1100 \pm 100 \mathrm{BP})$ and occupational levels VI $(880 \pm 100 \mathrm{BP})$ and VII (640 $\pm 100 \mathrm{BP}$ ), according to ${ }^{14} \mathrm{C}$ dating. Forte Marechal Luz site may exemplify the patterns of contact and mobility signaled by Neves (1988) and Mello e Alvim and Mendonça de Souza (1984). The artifacts, human skeletal remains, and fauna recovered from the excavations belong to the collection in the Biological Anthropology Division of the National Museum, Federal University of Rio de Janeiro (UFRJ), Rio de Janeiro, Brazil.

\section{STUdY MATERIAL}

After surveying the human skeletal remains, teeth preserving the dental enamel were separated from most of the individuals buried at Forte Marechal Luz sambaqui. Molar teeth were selected preferentially because of their larger amount of tooth enamel. In case of individuals without molars, the analyses were performed using premolars or incisors. A total of 32 specimens was analyzed, corresponding to 32 individuals. Of these, 21 individuals belonged to the occupation without ceramic (archeological layers without pottery) and 11 to the occupation with ceramic (archeological layers with pottery). We also analyzed dental enamel samples from four specimens of archeological land fauna associated with the site, including three teeth from three peccaries (Tayassu albirostris) and one tooth from a paca (Cuniculus paca). A sample of cockle shell (Anomalocardia brasiliana) removed from the same site was also analyzed.

\section{TREATMENT OF MATERIAL AND ANALYSIS}

In order to eliminate incrustations and diagenetic contamination, the teeth were submitted to mechanical and chemical cleaning. The dental crown surface was scraped with a number-12 scalpel in order to remove any gross material. Next, the teeth were placed separately in Teflon recipients with 5\% acetic acid and left in ultrasound for 20 minutes.

The dental enamel was removed using a diamond drill (model PM-7, KG Sorensen brand), previously tested to rule it out as a possible source of strontium contamination. Some $20 \mathrm{mg}$ of enamel sample were obtained from one of the lateral surfaces of the dental crown for each specimen. The analyses of the 32 dental enamel samples followed two distinct procedures, but with the same level of accuracy. In the first procedure, 10 samples of $20 \mathrm{mg}$ were weighed and transferred to Teflon beakers. Next, the chemical treatment began with the addition of $2 \mathrm{ml}$ of concentrated nitric acid $(14 \mathrm{~N})$. The samples were digested in approximately 90 minutes. Next, each sample was placed in a $2 \mathrm{ml}$ Eppendorf micro-tube for 10 minutes of centrifuging. After centrifuging it, a $1 \mathrm{ml}$ aliquot of this solution was transferred to a Teflon recipient and placed on a hotplate until the total evaporation of the acid phase. After the evaporation, the residue was recovered with the addition of $5 \mathrm{ml}$ of nitric acid (3\%). The isotope ratio was determined with a multi-collector inductively coupled plasma mass spectrometer MC-ICP-MS (Neptune, Thermo Scientific) at the Geochronology Laboratory of the Institute of Geosciences, University of Brasília (UnB), in Brasília.

The second procedure, which was done with the remaining 22 samples of human enamel plus 5 fauna samples, followed the same attack as the previous procedure. Subsequently, strontium spike was added, the function of which is to determine the strontium concentration in the samples by isotopic dilution, and chromatographic Sr separation was performed. Isotopic composition was determined by a multi-collector solid-source mass spectrometry (TIMS MAT 262, Thermo-Finnigan) at the Institute of Geosciences of UnB.

The accuracy and reproducibility of the analytical protocol in both procedures were verified by means of a standard solution of 200ppb strontium from the NIST SRM 987 reference material. During the analyses, this standard value showed little variation (from 0.71024 to $0.71030)$.

\section{RESULTS}

The mean isotope ratio in the dental enamel of the 32 individuals was 0.70950 . The lowest value was obtained for the individual with burial number 55, with a ratio of 0.70761; the highest value was for the individual burial number 26, with a ratio of 0.71064 . Although some 
variation was observed in the values observed in this series, most of the results were concentrated in a narrow range (see Table II).

The samples from the three peccaries (Tayassu pecari) and the paca (Cuniculus paca) showed values from 0.71046 to 0.71273 . The cockle sample (Anomalocardia brasiliana) showed an isotope ratio of 0.70917 (see Table I), close to that of present-day oceans (0.7092) (Wright 2005).

TABLE I

${ }^{87} \mathbf{S r} /{ }^{86} \mathbf{S r}$ isotope ratios for land and marine fauna in Forte Marechal Luz. Material analyzed with TIMS (thermal ionization mass spectrometry).

\begin{tabular}{c|c|c}
\hline Fauna & ${ }^{87} \mathrm{Sr} /{ }^{86} \mathrm{Sr}$ & $\mathrm{ppm} \mathrm{Sr}$ \\
\hline Peccary 1 & $0.71046 \pm 5$ & 214 \\
Peccary 2 & $0.71273 \pm 3$ & 274 \\
Peccary 3 & $0.71059 \pm 6$ & 142 \\
Paca & $0.71114 \pm 1$ & 850 \\
Seashell & $0.70917 \pm 3$ & 1126 \\
\hline
\end{tabular}

Based on the ${ }^{87} \mathrm{Sr} /{ }^{86} \mathrm{Sr}$ values for the fauna samples of the site, we determined the local biological ratio range for strontium: from 0.70917 (for the Anomalocardia brasiliana sample) to 0.71273 (Tayassu pecari). Individuals with ratios below the range were classified as non-locals; the rest was classified as local. Some individuals outside the range but close to it were included as locals. A total of three individuals, representing $9.4 \%$ of all the individuals analyzed, was considered non-locals (burials 11, 19, 55) because they present strontium isotopic ratios below the biological range of the local signature. The other 29 individuals present a restrict range of ${ }^{87} \mathrm{Sr} /{ }^{86} \mathrm{Sr}$ variation, falling inside the local biological strontium ratio range and being classified as locals. Figure 1 illustrates the strontium ratio distribution for the analyzed individuals and the local biological strontium ratio range.

Separating the individuals buried in the archeological layers without pottery from those with pottery, we observed a slight tendency for the strontium ratio to be higher in the individuals buried in the pottery layers (more recent occupation) when compared to the individuals buried in the layers without pottery (older occupation), with the difference in the isotope ratios be- tween the occupation of the site illustrated in the boxplot (Fig. 2). Among the individuals classified as nonlocals, two were buried in the ceramic occupation and one in the pre-ceramic pottery occupation.

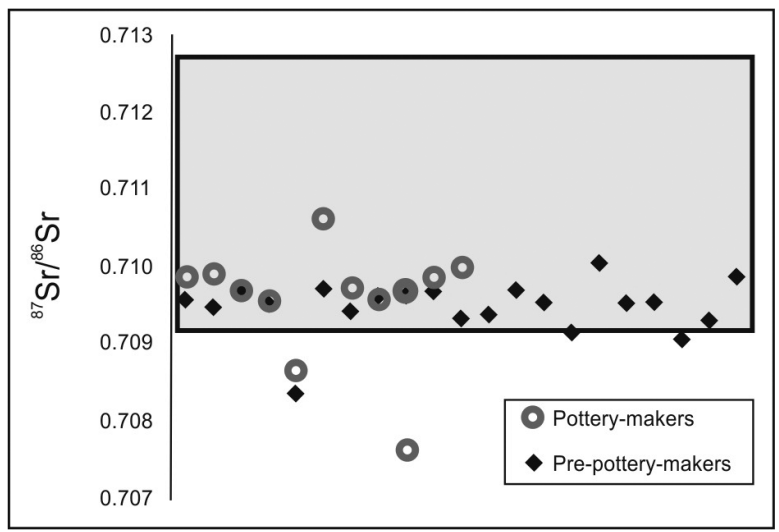

Fig. 1 - Relationship between the strontium isotope ratios for individuals from the archeological sequence with pottery (pottery-makers) and without pottery (pre-pottery-makers) and the range of the local biological signature. The lower limit set for the local biological signature is also the present marine strontium ratio.

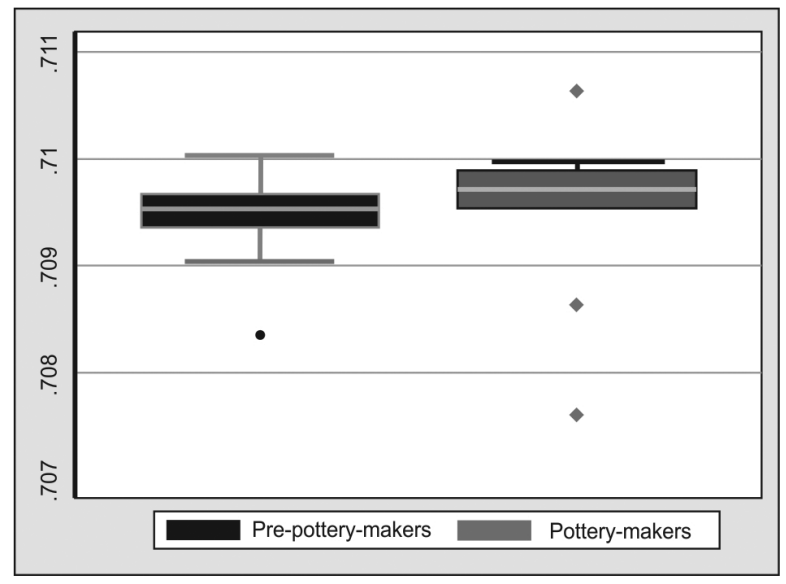

Fig. 2 - Box-plot of the strontium isotope ratios for individuals buried in the archeological sequences with and without pottery in Forte Marechal Luz site. The dashed line shows the present marine strontium ratio.

\section{DISCUSSION}

Based on these findings, two sets of questions will be discussed. Firstly, we examine the question of residential mobility for individuals buried in Forte Marechal Luz sambaqui; secondly, we discuss the origin of the strontium assimilated in the dental enamel of the indi- 
TABLE II

${ }^{87} \mathrm{Sr} /{ }^{86} \mathrm{Sr}$ isotope ratio in individuals buried at the Forte Marechal Luz site, organized by burial number. M (molar); P (premolar); I (incisor); L (left); R (right).

\begin{tabular}{l|c|c|c|l}
\hline $\begin{array}{c}\text { Location }- \\
\text { municipality }\end{array}$ & State & Dating (oldest - most recent) & $\begin{array}{c}\text { Distance } \\
\text { from FML }\end{array}$ & \multicolumn{1}{c}{ Source } \\
\hline Urubici & SC & $910 \mathrm{BP}-330 \pm 90 \mathrm{BP}$ & $230 \mathrm{~km}$ & Piazza 1966, Schmitz 1988 \\
\hline São Joaquim & SC & $1920 \pm 50-1117 \pm 80 \mathrm{BP}$ & $270 \mathrm{~km}$ & Schmitz and Brochado 1972 \\
\hline Esmeralda & RS & $650 \pm 55 \mathrm{BP}-355 \pm 50 \mathrm{BP}$ & $330 \mathrm{~km}$ & Ribeiro and Ribeiro 1985 \\
\hline Campo Largo & PR & $848 \pm 70 \mathrm{BP}-558 \pm 50 \mathrm{BP}$ & $130 \mathrm{~km}$ & Chmyz 1995 \\
\hline Curitiba & PR & $940 \pm 70 \mathrm{BP}-660 \pm 60 \mathrm{BP}$ & $120 \mathrm{~km}$ & Chmyz et al. 2003 \\
\hline Cananéia & SP & $7870 \pm 80 \mathrm{BP}-3170 \pm 95 \mathrm{BP}$ & $140 \mathrm{~km}$ & $\begin{array}{l}\text { Uchôa and Garcia 1983, } \\
\text { Calippo 2004 }\end{array}$ \\
\hline
\end{tabular}

viduals and the differences in the isotope ratios between those buried in the archeological layers without pottery (pre-pottery occupation) and in the archeological layers with pottery (pottery occupation).

According to the analysis of strontium isotopes in 32 individuals buried in both layers (with and without the presence of pottery) in Forte Marechal Luz site, three individuals were non-locals. In other words, the dental enamel analysis showed different strontium ratios from the local ratios, indicating that these individuals spent the early years of their lives (when the enamel was formed) in other regions. Of these, two were buried in the layer with pottery and one in the layer without pottery. The identification of a non-local individual buried in the layer without pottery indicates that there was mobility in the site even before the introduction of pottery from the Itarare Ceramic Tradition, i.e., before $880 \pm 100 \mathrm{BP}$. The presence of pottery itself can be taken as an evidence of contact, reinforced by the identification of two non-local individuals buried in the layer with pottery.

The individuals that were considered non-locals had low strontium isotope ratios, which is characteristic of regions with mantle derived magmatic rocks, generally volcanic in origin. From the geological point of view, rocks with low strontium isotope ratios are found in the basaltic plateau and in alkaline complexes in Santa Catarina, Paraná, and São Paulo. With heights generally greater than $800 \mathrm{~m}$ and broad lateral extension, the basaltic rocks on the plateau date to the Cretaceous and present a wide variation in the strontium isotope composition ( 0.705 to 0.713$)$, revealing different degrees of crustal contamination (Mantovani et al. 1985, Marques et al. 1999). Meanwhile, the alkaline complexes are volcanic to sub-volcanic structures with localized occurrence and strontium isotope ratios of around 0.705 (Morbidelli et al. 1995, Walter et al. 1995, Huang et al. 1995, Ruberti et al. 2002). The alkaline complexes closest to Forte Marechal Luz are located in the municipalities of Juquiá, Jacupiranga, Cananéia, Tunas, Mato Preto, Barra do Itapirapuã, and Itapurapuã.

A literature survey was conducted of archeological sites in areas with low strontium isotope ratios in the attempt to identify the original home region of the non-local individuals buried in Forte Marechal Luz site. A possible original region for such individuals is in the Santa Catarina Plateau close to the municipality (county) of Lages, where there are records of ceramic sites associated with the Itararé Tradition. The closest sites to Forte Marechal Luz are in the municipality of Urubici, approximately $230 \mathrm{~km}$ away. The sites date from 910 BP to 330 BP (Piazza 1966, Schmitz 1988). Sites have also been described in the municipality of Lages, approximately $250 \mathrm{~km}$ from Forte Marechal Luz (Rohr 1971), and sites also in the municipality of São Joaquim, Santa Catarina, $270 \mathrm{~km}$ away, dating to approximately $1120 \mathrm{BP}$ (Schmitz and Brochado 1972). More recent sites were described by Ribeiro and Ribeiro (1985) in the municipality of Esmeralda, Rio Grande do Sul, $330 \mathrm{~km}$ away, dating from $650 \mathrm{BP}$ to $350 \mathrm{BP}$. The chronological proximity between some of these sites and the burials at Forte Marechal Luz, in addition to the evidence of similar pottery in both places, reinforces the hypothesis of contact between a plateau prehistoric group and a coastal group using Forte Marechal Luz site. 
Other sites belonging to the Itarare Tradition are located at the Paraná state Plateau, at the municipality of Campo Largo, western to Curitiba (Chmyz 1995). Those sites are approximately at $130 \mathrm{~km}$ from Forte Marechal Luz, dating from 848 BP to 558 BP. There are also records of sites of the same ceramic tradition located in the municipality of Curitiba (Chmyz et al. 2003), approximately $120 \mathrm{~km}$ from Forte Marechal Luz, dating from $940 \mathrm{BP}$ to $660 \mathrm{BP}$. In both cases, Forte Marechal Luz site can be associated with such occupations based on the chronology, the presence of pottery shards, and the signature of origin of the three individuals that diverge from the coastal strontium ratio pattern.

The sites close to the municipality of Lages are located an average of $270 \mathrm{~km}$ from the Forte Marechal Luz sambaqui, and are close to or on the Santa Catarina Plateau, of basaltic origin, which has rocks with a low ${ }^{87} \mathrm{Sr} /{ }^{86} \mathrm{Sr}$ ratio. Nearby there are also alkaline igneous rocks with a low ${ }^{87} \mathrm{Sr} /{ }^{86} \mathrm{Sr}$ ratio. Meanwhile, the sites close to Curitiba are found near the areas with alkaline igneous rocks, and are $125 \mathrm{~km}$ from Forte Marechal Luz, i.e., less than half the distance of the sites located on the Santa Catarina Plateau. A possible contact between the inhabitants of Forte Marechal Luz and the Curitiba Plateau would have been facilitated by both the shorter distance between these locations and a river basin originating in the latter and flowing into the northern coast of Santa Catarina, in Babitonga Bay.

A third region with rocks having a low strontium isotope ratio would be Cananéia, located in southern São Paulo State. The sedimentary plain, called the CananéiaIguape Coastal Plain, has one of the highest known concentrations of sambaquis on the Brazilian coast (Uchôa and Garcia 1983). The dates obtained for the Cananéia sites (from 8000 BP to approximately 4000 BP) suggest that these occupations were not contemporaneous with the occupations analyzed at Forte Marechal Luz site. In the future, more detailed studies of the chronology of these sites located in southern São Paulo may validate the hypothesis of contact between the inhabitants of Forte Marechal Luz and Cananéia. At present, however, it is not possible to consider Cananéia the origin of the non-local individuals at Forte Marechal Luz since in addition to the distinct chronology between the sites, no evidence was found of pottery from the Itarare Tradition in these Cananéia sites. Table III and Figure 3 present details of the municipalities cited above.
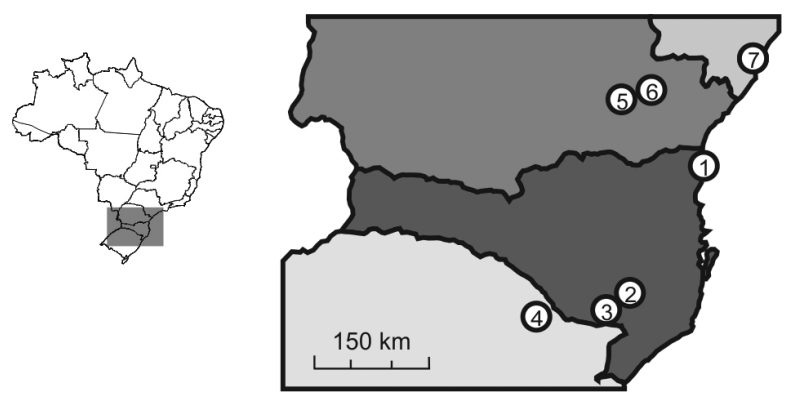

Fig. 3 - Southern Brazil with all cited localities/municipalities. Locality 1 - Forte Marechal Luz site; 2 - Urubici-SC; 3 - São JoaquimSC; 4 - Esmeralda-RS; 5 - Campo Largo-PR; 6 - Curitiba-PR; 7 - Cananéia-SP.

Concerning the assimilation of strontium and the difference between the two occupations, the isotope findings for the individuals classified as locals in this study indicate a strong marine influence in the origin of the strontium assimilated into the apatite molecules from the dental enamel. The ${ }^{87} \mathrm{Sr} /{ }^{86} \mathrm{Sr}$ ratios obtained for local individuals are close to the ratio found in the seawater (0.7092). The isotopic proximity of the individuals to the marine ratio signals the prevalence of a marine diet for those that inhabited and were buried in Forte Marechal Luz site. Nevertheless, this dietary prevalence does not rule out terrestrial sources. Analyses of micro-residues from dental calculi indicate that the inhabitants of the site had in their diets plants like yams (Dioscorea sp.) (Wesolowski 2007).

In addition to plants, land animals were part of the diet, given that the site yielded skeletal remains of medium and large-sized land animals like peccaries (Tayassu pecari), pacas (Cuniculus paca), deers (Hispardalis sp.) and others (Bryan 1993). Unlike the other samples analyzed in this study, the land fauna specimens showed high strontium isotope values. Such ratios indicated that the strontium assimilated in the dental enamel of these animals received little or no influence from marine strontium, but rather from that originating in the geological formations between the coast and the basaltic plateau in southern Brazil. The fauna that was analyzed consists of peccaries and tapirs, which can be 
TABLE III

Municipalities with sites belonging to the Itararé Tradition and sambaquis in Cananéia with low strontium isotope ratio. SC - Santa Catarina State; RS - Rio Grande do Sul State; PR - Paraná State; SP - São Paulo State; FML - Forte Marechal Luz sit.

\begin{tabular}{|c|c|c|c|c|c|c|}
\hline Burial & $\begin{array}{l}\text { Archeological } \\
\text { sequence }\end{array}$ & Tooth & Sex & ${ }^{87} \mathrm{Sr} /{ }^{86} \mathrm{Sr}$ & ppm Sr & Method \\
\hline 1 & Pre-pottery & M3, upper L & Female & $0.70956 \pm 6$ & & ICP-MS \\
\hline 2 & Pottery & M1, upper R & Undetermined & $0.70986 \pm 3$ & 127 & TIMS \\
\hline 4 & Pottery & M1, lower L & Male & $0.70990 \pm 5$ & & ICP-MS \\
\hline 5 & Pottery & M3, upper L & Male & $0.70968 \pm 3$ & 146 & TIMS \\
\hline 6 & Pre-pottery & M2, lower R & Female & $0.70947 \pm 3$ & 157 & TIMS \\
\hline 8 & Pre-pottery & M2, upper R & Undetermined & $0.70967 \pm 7$ & & ICP-MS \\
\hline 10 & Pre-pottery & M2, upper L & Male & $0.70951 \pm 6$ & & ICP-MS \\
\hline 11 & Pre-pottery & M1, lower R & Male & $0.70835 \pm 3$ & 165 & TIMS \\
\hline $11 \mathrm{~B}$ & Pre-pottery & M3, lower L & Female & $0.70970 \pm 1$ & 137 & TIMS \\
\hline 18 & Pottery & M1, lower R & Undetermined & $0.70956 \pm 6$ & 100 & TIMS \\
\hline 19 & Pottery & $\mathrm{M} 2$ & Undetermined & $0.70864 \pm 2$ & 274 & TIMS \\
\hline 20 & Pre-pottery & M2, upper L & Undetermined & $0.70941 \pm 5$ & 170 & TIMS \\
\hline 22 & Pre-pottery & M2, upper L & Male & $0.70960 \pm 7$ & & ICP-MS \\
\hline 23 & Pre-pottery & M2, lower R & Male & $0.70961 \pm 3$ & 129 & TIMS \\
\hline 24 & Pre-pottery & M1, lower R & Undetermined & $0.70967 \pm 9$ & & ICP-MS \\
\hline 26 & Pottery & M2, upper L & Undetermined & $0.71064 \pm 3$ & 162 & TIMS \\
\hline 27 & Pottery & M2, lower L & Undetermined & $0.70971 \pm 3$ & 148 & TIMS \\
\hline 32 & Pre-pottery & I1, upper R & Female & $0.70932 \pm 3$ & 187 & TIMS \\
\hline 35 & Pre-pottery & M2, lower R & Undetermined & $0.70936 \pm 2$ & 184 & TIMS \\
\hline 36 & Pre-pottery & M3, lower L & Male & $0.70968 \pm 4$ & 145 & TIMS \\
\hline 37 & Pre-pottery & M2, upper R & Undetermined & $0.70953 \pm 4$ & 146 & TIMS \\
\hline 38 & Pre-pottery & $\mathrm{M} 2$, upper $\mathrm{R}$ & Undetermined & $0.70914 \pm 4$ & 119 & TIMS \\
\hline 39 & Pre-pottery & M2, upper L & Undetermined & $0.71003 \pm 2$ & 101 & TIMS \\
\hline 40 & Pre-pottery & M3, upper R & Undetermined & $0.70952 \pm 5$ & & ICP-MS \\
\hline 43 & Pre-pottery & M2, upper R & Female & $0.70953 \pm 3$ & 139 & TIMS \\
\hline 48 & Pre-pottery & M1, lower R & Undetermined & $0.70905 \pm 1$ & 110 & TIMS \\
\hline 50 & Pre-pottery & M2, upper L & Undetermined & $0.70929 \pm 5$ & & ICP-MS \\
\hline 52 & Pottery & M3, upper R & Undetermined & $0.70954 \pm 6$ & & ICP-MS \\
\hline 55 & Pottery & M3, upper L & Undetermined & $0.70761 \pm 2$ & 266 & TIMS \\
\hline 56 & Pottery & M2, upper R & Undetermined & $0.70985 \pm 7$ & 145 & TIMS \\
\hline $59 \mathrm{~B}$ & Pottery & M1, lower L & Undetermined & $0.70997 \pm 4$ & & ICP-MS \\
\hline 61 & Pre-pottery & P2, upper L & Undetermined & $0.70985 \pm 7$ & & ICP-MS \\
\hline
\end{tabular}

hunted in the inland forests in the region, on crystalline terrains. These specimens may also have reached the coast through bartering of items among different groups.

Comparing the individuals buried in the archeological layer without evidence of ceramic shards and those in the layers with ceramic, we observed that the latter present a slightly higher strontium ratio than the prepottery individuals. This fact can be explained by the slight changes in the dietary pattern between these two periods in the occupation of the site. Pre-pottery individuals present a mean ${ }^{87} \mathrm{Sr} /{ }^{86} \mathrm{Sr}$ ratio closer to the marine ratio. Although tenuous, this could be an indication that the pre-pottery occupants made greater use of coastal food resources as the basis of their diet, as compared to those that inhabited the site later. Various authors have associated the introduction of pottery in the sambaquis with the change in dietary pattern (Prous 1991, Piazza 1966). 
The differences in strontium ratio thus suggest that the introduction of pottery in Forte Marechal Luz site may be associated not only with the acquisition of the pottery-making technique, but also with changes in eating habits, perhaps involving a behavior with more inland forays or a more striking seasonal behavior between the coast and plateau for the local population. Bryan (1993) recorded an increase in the occurrence of land fauna in the pottery occupational levels, compared to the pre-pottery levels, which is consistent with the differences observed in the current study. Thus, the introduction of new individuals and new habits, including the use of plant foodstuffs acquired in geologically different terrains, in addition to animals brought from the mountainside forests or even from the plateaus, seems to be another archeological evidence in the ceramic layers from Forte Marechal Luz shellmound.

Finally, it is important to mention the limitations of this study. Forte Marechal Luz site yielded only a few specimens of land fauna with teeth that could be used in the analysis, making the determination of the range in the local biological signature that represented the real isotopic variation in the region of the site less reliable. However, it is important to mention that the land fauna presented high strontium isotope values, higher than the mean obtained for more than $90 \%$ of the individuals, which showed a strontium ratio close to that of the strontium from the seawater and marine fauna. The other individuals, classified as non-local, showed results below the marine strontium ratio.

The fact that Forte Marechal Luz site, like other sambaquis, was formed mainly by the accumulation of Anomalocardia brasiliana shells, together with other marine mollusks (Bryan 1961, Gaspar 2000), increases the risk of diagenesis (i.e., the contamination of samples by strontium from mollusk shells) maybe jeopardizing the results of this analysis. The adherence of strontium leached from these shells, as well as from the soil and water, to human bone and teeth, could theoretically cause the homogenization of isotope ratios, i.e., the replacement of biogenic strontium by that of external origin (Horn and Müller-Sohnius 1999). In the case of the material buried in Forte Marechal Luz, such homogenization would tend to shift the strontium ratios toward the marine ratio $(0.7092)$, since the shells, ma- rine sedimentary soil, and water present in the location have this ratio. However, considering that the values observed in the samples varied from 0.70761 (human enamel from individual 55) to 0.71273 (dental enamel from a peccary in the site), one can state that there was no homogenization of the samples, or that it was not complete. We can assume that if diagenetic contamination of the material indeed occurred, it was not capable of leveling the values, i.e., of masking the different biogenic signatures of the individuals and animals buried in the site.

\section{FINAL REMARKS}

The analyses performed in this study point to the existence of residential mobility in the Forte Marechal Luz sambaqui. The individuals classified as non-locals probably came from the Santa Catarina Plateau (close to the municipality of Lages) or the Paraná Plateau (close to the municipality of Curitiba). Still, we cannot rule out the possibility that they came from the southern coast of São Paulo, from sites located in the municipality of Cananéia, although there is no known contemporaneity between the sites from that region and Forte Marechal Luz site.

The presence of a non-local individual buried in the archeological layer without pottery indicates that the contact between groups occurred before pottery was introduced in the site. The similarity between the strontium isotope ratio in individuals classified as locals and the strontium ratio in the ocean indicates a strong marine influence in the source of strontium for these individuals. The slight difference in the isotope ratios comparing locals individuals buried in layers without pottery to those buried in layers with pottery suggests dietary changes between these periods of the occupation of the site. Finally, it is important to highlight that the successful identification of non-local individuals in the current study opens up possibilities for future research using strontium isotope analysis in sambaquis.

\section{ACKNOWLEDGMENTS}

We thank the Conselho Nacional de Desenvolvimento Científico e Tecnológico (CNPq), grant no. 400.474/ 2006, and the Fundação Carlos Chagas Filho de Amparo à Pesquisa do Estado do Rio de Janeiro (FAPERJ), 
grant no. E-26/102.935/2008), for financial support. We also thank M.Sc. Jeane Grasyelle Silva Chaves and Bachelor Hadriadne Gomes de Azevedo de Sousa of Laboratório de Geocronologia of Universidade de Brasília for the analytical support. Dr. Andersen Liryo da Silva of Departamento de Antropologia do Museu Nacional-UFRJ for teeth identification support, Prof. Dr. Maria Dulce Gaspar of Departamento de Antropologia do Museu Nacional-UFRJ and Prof. Dr. Claudio de Morisson Valeriano of Departamento de Geologia da Universidade Estadual do Rio de Janeiro for helpful comments on this paper.

\section{RESUMO}

O presente estudo investigou isótopos de estrôncio em esmalte dentário de 32 remanescentes humanos do sambaqui do Forte Marechal Luz, Santa Catarina, Brasil, com o objetivo de identificar indivíduos locais e não-locais. O sítio arqueológico apresenta fragmentos de cerâmica em suas camadas arqueológicas mais recentes. Além das amostras humanas, foram analisadas amostras de esmalte dentário de espécimes de fauna terrestre $\left({ }^{87} \mathrm{Sr} /{ }^{86} \mathrm{Sr}=0,71046\right.$ a 0,71273$)$ e fauna marinha $\left({ }^{87} \mathrm{Sr} /{ }^{86} \mathrm{Sr}=0,70917\right)$. A razão ${ }^{87} \mathrm{Sr} /{ }^{86} \mathrm{Sr}$ dos indivíduos classificados como locais variou de 0,70905 a 0,71064 , sendo próxima a razão de estrôncio existente nos oceanos e distante da razão obtida para a fauna terrestre do mesmo sítio, indicando uma influência marinha na origem do estrôncio dos habitantes desse sambaqui. Foram identificados de três indivíduos não locais $\left({ }^{87} \mathrm{Sr} /{ }^{86} \mathrm{Sr}=0,70761\right.$ a 0,70835$)$, sepultados em ambas camadas arqueológicas sem evidência e com evidência de cerâmica. Estes indivíduos podem ter origem no planalto catarinense, no entorno do município de Lages, ou do planalto curitibano. A ocorrência de uma pequena diferença entre as razões isotópicas dos indivíduos locais sepultados nas camadas sem evidência de cerâmica, daqueles sepultados nas camadas ceramistas, sugere a possibilidade de uma mudança nos padrões de alimentação entre esses dois momentos de ocupação do sítio.

Palavras-chave: Brasil, mobilidade humana, isótopos, préhistória, sambaqui, estrôncio.

\section{REFERENCES}

Apostolopoulos Y And Sönmez S. 2007. Population Mobility and Infectious Disease. New York: Springer, $319 \mathrm{p}$.
BANDEIRA DR. 2004. Ceramistas pré-coloniais da baía da Babitonga, SC: Arqueologia e etnicidade. Campinas, Universidade: Estadual de Campinas, 257 p.

BARRETo CNGB. 1988. A ocupação pré-colonial do Vale do Ribeira de Iguape, SP: os sítios concheiros do médio curso. São Paulo, Universidade de São Paulo, 339 p.

BECK A. 1971. Grupos cerâmicos do litoral de Santa Catarina - Fase Rio Lessa e Fase Enseada. An Mus Antropol 4: $25-29$.

BECK A. 1972. A variação do conteúdo cultural dos sambaquis - litoral Santa Catarina. São Paulo, Faculdade de Filosofia Letras e Ciências Humanas da USP, 286 p.

Bentley RA, Krause R, Price TD and Kaufmann B. 2003. Human mobility at the early Neolithic settlement of Vahingen, Germany: evidence from strontium isotope analysis. Archaeometry 44: 471-486.

Bentley RA, Price DT And Stephan E. 2004. Determining the "local" ${ }^{87} \mathrm{Sr} /{ }^{86} \mathrm{Sr}$ range for archaeological skeletons: a case study from Neolithic Europe. J Archaeol Sci 31: 365-375.

BRYAN AL. 1961. Excavation of a Brazilian Shellmound. Sci Man 1(5): 148-151.

BRYAN AL. 1993. The Sambaqui at Forte Marechal Luz, State of Santa Catarina, Brazil. Corvallis: Center for the Study of the First Americans/Oregon State University, $168 \mathrm{p}$.

BRYAN AL. 1997. The Sambaqui do Forte Marechal Luz State of Santa Catarina, Brazil. Center of Study of the First Americans, Oregon: Oregon State University, p. 89-108.

Budd P, Millard A, Chenery C, Lucy S And RoBERTS C. 2004. Investigating population movement by stable isotope analysis: a report from Britain. Antiquity 78: $127-141$.

BUZON MR. 2006. Biological and ethnic identity in New Kingdom Nubia: a case study from Tombos. Curr Anthropol 47: 683-695.

CAlippo FL. 2004. Os sambaquis submersos de Cananéia: Um estudo de caso de arqueologia subaquática. São Paulo, Universidade de São Paulo, 151 p.

Chmyz I. 1995. Arqueologia de Curitiba. B. Inf. Casa Romário Martins 21(105): 5-54.

Chmyz I, Bora E, Santos Ceccon R, Sganzerla ME AND Volcov JE. 2003. A arqueologia da área do aterro Sanitário da região metropolitana de Curitiba, em Mandirituba, Paraná. Arqueologia 2: 1-138.

DE MASI MAN. 2001. Evolução da Dieta das Populações Pré-históricas da Costa Sul do Brasil, Santa Catarina. In: 
XI Congresso da Sociedade de Arqueologia BrasileirA, Rio de Janeiro. An XI Congr Soc Arqueol Bras, p. 1-136.

ERICSON JE. 1986. Strontium isotope characterization in the study of prehistoric human ecology. J Hum Evol 14: 503-514.

Evans J, Stoodley N And Chenery C. 2006. A strontium and oxygen isotope assessment of a possible fourth century immigrant population in a Hampshire cemetery, southern England. J Archaeol Sci 33: 265-272.

Ezzo JA, Johnson CM And PRICE TD. 1997. Analytical perspectives on prehistoric migration: a case study from east-central Arizona. J Archaeol Sci 24: 447-466.

FAURE G. 1986. Principles of Isotope Geology. Willey ed., $608 \mathrm{p}$.

FAURE G AND POWELL JL. 1972. Strontium Isotope Geology. Springer-Verlag, New York, 188 p.

FigUti L. 1993. O homem pré-histórico, o molusco e o sambaqui. R Mus Arqueol Etnol USP 3: 67-80.

GASPAR MD. 1991. Aspectos da organização social de um grupo de pescadores, coletores e caçadores: Região compreendida entre a Ilha Grande e o delta do Paraíba do Sul, Estado do Rio de Janeiro. São Paulo. Universidade de São Paulo, 374 p.

GASPAR MD. 2000. Sambaqui: Arqueologia do litoral brasileiro. Rio de Janreiro: Jorge Zahar Editor, 89 p.

Gaspar MD, DeBlasis P, Fish SK AND Fish PR. 2008. Sambaqui (Shell Mound) Societies of Costal Brazil. Handbook of South American Archaeology, Springer, p. 319-335.

Grupe G, Price TD, Schröter P, Söllner F, JohnSON CM AND BEARD BL. 1997. Mobility of Bell Beaker people revealed by strontium isotope ratios of tooth and bone: a study of southern Bavarian skeletal remains. Appl Geochem 12: 517-525.

Higashi RR, Davison Dias R, Mafra Jr CS, Coelho DA And Martins KP. 2001. Análise do Subsolo de Santa Catarina Visando a Implantação de Rodovias. Reunião Anual de Pavimentação. Florianópolis, 8 p.

Hillson S. 1996. Dental Anthropology. Cambridge: Cambridge University Press, $373 \mathrm{p}$.

Hodell DA, Quinn RL, BRenner M AND KAMENov G. 2004. Spatial variation of strontium isotopes $\left({ }^{87} \mathrm{Sr} /{ }^{86} \mathrm{Sr}\right)$ in the Maya region: a tool for tracking ancient human migration. J Archaeol Sci 31: 585-601.

Hoppe KA, Koch PL and Furutani TT. 2003. Assessing the preservation of biogenic strontium in fossil bones and tooth enamel. Inter J Osteoarchaeol 13: 20-28.
Horn P AND Müller-Sohnius D. 1999. Comment on Grupe et al. (1997). Appl Geochem 14: 263-269.

Huang YM, Hawkesworth CJ, Calsteren P Van AND MCDEMOTT F. 1995. Geochemical characteristics and origin of the Jacupiranga carbonatites, Brazil. Chem Geol 119: 79-99.

Knudson KJ, Price TD, Buikstra JE And Blom DE. 2004. The use of strontium isotope analysis to investigate Tiwanaku migration and mortuary ritual in Bolivia and Peru (Part1). Archaeometry 46: 5-18.

LIMA TA. 1999-2000. Em busca dos frutos do mar: os pescadores-coletores do litoral centro-sul do Brasil. R USP, p. 270-327.

Mantovani MSM, Marques LS, Sousa MA, Atalla LT, CIVETTA L AND INNOCENTI F. 1985. Trace element and strontium isotope constraints on the origin and evolution of Paraná continental flood basalts of Santa Catarina State (southern Brazil). J Petrol 26: 187-209.

Marques LS, Dupré B AND PiCCIRILlo EM. 1999. Mantle source compositions of the Paraná Magmatic Province (southern Brazil): evidence from trace element and $\mathrm{Sr}-\mathrm{Nd}-\mathrm{Pb}$ isotope geochemistry. J Geodynam 28: 439458.

Mello E Alvim MC de And Mendonça de Souza SMF. 1984. Os Índios Kaingang e a População do Forte Marechal Luz. An J Bras Arqueol Rio de Janeiro: Instituto Superior de Cultura Brasileira, p. 3-4.

Miller EK, Blum JA And Firiedland AJ. 1993. Determination of soil exchangeable-cation loss and weathering rates using Sr isotopes. Nature 362: 438-441.

Montgomery J, Budd P, Cox A, Krause P And ThomAs RG. 1999. LA-ICP-MS evidence for the distribution of lead and strontium in Romano-British, medieval and modern human teeth: implications for life history and exposure reconstruction. In: YOUNG SMM, POLlARd AM, BUdD P AND IXER RA (Eds), Metals in Antiquity, BAR International Series, Archaeopress, Oxford 792: 258-261.

Morbidelli L, Gomes CB, Beccaluva L, Brotzu P, Conte AM, Ruberti E And Traversa G. 1995. Mineralogical, petrological and geochemical aspects of alkaline and alkaline-carbonatite associations from Brazil. Earth Sci Rev 39: 135-168.

Neves WA. 1988. Paleogenética dos grupos pré-históricos do litoral sul do Brasil (Paraná e Santa Catarina). Pesquisas (Antropologia) 43: 178.

PiAZZA W. 1966. As grutas de São Joaquim e Urubici. Notas de Pesquisa. Universidade Federal de Santa Catarina. Instituto de Antropologia. Série arqueológica 1: 53. 
Price TD, Burton JH AND BEntley RA. 2002. The characterization of biologically available strontium isotope ratios for the study of prehistoric migration. Archaeometry 44: 117-136.

Price TD, Grupe G ANd Schröter P. 1998. Migration and Mobility in the Bell Beaker period in Central Europe. Antiquity 72: 405-411.

Price TD, Knipper C, Grupe G And SmrCKA V. 2004. Strontium isotopes and prehistoric human migration: the Bell Beaker Period in Central Europe. Eur J Archaeol 7: $9-40$.

Price TD, Manzanilla L And Middleton WD. 2000. Immigration and the ancient city of Teotihuacan in Mexico: A study using strontium isotope ratios in human bone and teeth. J Archaeol Sci 27(10): 903-913.

Prous A. 1991. Arqueologia Brasileira. Brasília: Editora UNB, $613 \mathrm{p}$.

RIBEIRO PAM AND RIBEIRO CT. 1985. Levantamentos arqueológicos no município de Esmeralda, RS, Brasil. R Cepa 13(15): 50-105.

RibeIRo PAM, RIBEIRo CT AND SILVEIRA I. 1977. A ocorrência de zoólitos no Planalto Meridional: Barros Cassal, RS, Brasil. R Cepa 5: 5-37.

ROHR JA. 1971. Os sítios arqueológicos do planalto catarinense, São Leopoldo: Pesquisas 24: 56.

Ruberti E, Castorina F, Censi P, COMin-ChiaraMOnTi P, Gomes CB, ANTONini P AND Andrade FRD. 2002. The geochemistry of the Barra do Itapirapuã carbonatite (Ponta Grossa Arch, Brazil): a multiple stockwork. J S Am Earth Sci 15: 215-228.

SCHEEL-YBERT R. 2001. Man and vegetation in southeastern Brazil during the late Holocene. J Archaeol Sci 28: 471480.

SCHMITZ PI. 1988. As tradições ceramistas do Planalto SulBrasileiro. Arqueologia do Rio Grande do Sul, Brasil São Leopoldo: Documentos 2: 75-130.
SCHMitz PI AND BRochado JP. 1972. Datos para una secuencia cultural del Estado de Rio Grande do Sul, Brasil. Gabinete de Arqueologia. Universidade Federal do Rio Grande do Sul, p. 1-20.

SchweIssing MM AND GRUPE G. 2003. Stable strontium isotopes in human teeth and bone: a key to migration events of the late Roman period in Bavaria. J Archaeol Sci 30: 1373-1383.

Sillen A AND KaVAnagh M. 1982. Strontium and paleodietary research: a review, Yearbk. Phys Anthropol 25: 67-90.

UCHÔA DP AND GARCIA CDR. 1983. Cadastramento dos sítios arqueológicos da baixada Cananéia-Iguape, litoral sul do estado de São Paulo, Brasil. R Arqueol Mus Paraense Emílio Goeldi 1(1): 91-113.

Walter AV, Flicoteaux R, Parron C, Loubet M And NAHON D. 1995. Rare-earth elements and isotopes ( $\mathrm{Sr}$, $\mathrm{Nd}, \mathrm{O}, \mathrm{C}$ ) in minerals from the Juquiá carbonatite (Brazil): tracers of a multistage evolution. Chem Geol 120: 27-44.

WesolowsKi V. 2007. Cáries, desgaste, cálculos dentários e micro-resíduos da dieta entre grupos pré-históricos do litoral norte de Santa Catarina: É possível comer amido e não ter cárie? Rio de Janeiro, Escola Nacional de Saúde Pública Sérgio Arouca, Fiocruz, 193 p.

Wesolowski V, MEndonça de Souza SMF, ReInHARd KJ And Ceccantini G. 2010. Evaluating microfossil content of dental calculus from Brazilian sambaquis. J Archaeol Sci 37: 1326-1338.

Wilson AS ET AL. 2007. Stable isotope and DNA evidence for ritual sequences in Inca child sacrifice. Proc Natl Acad Sci USA 104(42): 16456-16461.

Wright LE. 2005. Identifying immigrants to Tikal, Guatemala: defining local variability in strontium isotope ratios of human tooth enamel. J Archaeol Sci 32: 555-566. 